\title{
HUBUNGAN PENGETAHUAN DENGAN SIKAP ORANG TUA TENTANG TOILET TRAINING PADA ANAK TODDLER DI PAUD TUNAS CERIA
}

\author{
Tri Arini, Dewi Kusumaningtyas
}

\author{
Akademi Keperawatan YKY Yogyakarta Indonesia \\ Email : nengtriarini@yahoo.com
}

\begin{abstract}
Abstrak
Toilet training akan mengantarkan pada sikap taat norma dan perilaku bersih nan sehat pada anak. Peran serta kedua orang tua sangat diperlukan. Anak-anak yang mulai belajar toilet training dalam usia dua tahun atau lebih besar akan terlambat untuk menguasai pengendalian kandung kemih. Akibatnya anak akan lebih sering mengompol di usia sekolah. Tujuan penelitian ini adalah diketahuinya hubungan pengetahuan dengan sikap ibu tentang pelaksanaan toilet training pada anak usia toddler dengan jenis Deskriptif korelasional dengan menggunakan pendekatan cross sectional. Instrumen berupa kuesioner pada ibu anak usiatoddler. Analisis data menggunakan uji Chi Square.Penelitian ini pada bulan Februari 2014. Terdapat hubungan signifikan antara pengetahuan dengan sikap ibu tentang pelaksanaan toilet training pada anak usia toddler di PAUD Tunas Ceria Yogyakarta $(p<0,05)$.Pengetahuan terkait dengan sikap ibu terhadap pelaksanaan toilet training. Manajemen PAUD harus meningkatkan pengetahuan ibu, sehingga sikap terhadap pelaksanaan pelatihan toilet dapat menjadi lebih baik.
\end{abstract}

Kata Kunci : Pengetahun, Sikap, Toilet Training, Toddler.

\begin{abstract}
Toilet training will leads to obedient norms and attitudes clean and healthy behaviors in children. Participation of both parents is needed. Children who begin to learn toilet training at the age of two years or more will be too late to take control urinary bladder control. As a result, the child will be more frequent bedwetting in the school age. This study was to examine the relationship between knowledge an attitude toward toilet training implementation among mother who have toddler children in PAUD Tunas Ceria Yogyakarta. This study was descriptive correlational study using cross-sectional approach. The instrumenta questionnaire filled in my mother of toddler children. Data have using Chi Square. Data colection was conducted in February 2014. The study showed that there is a correlation between knowledge and attitude toward toilet training implementation among mother who have toddler children in PAUD Tunas Ceria Yogyakarta( $\mathrm{p}<0.05)$. Since the knowledge are related to mother attitude toward toilet training implementation. PAUD management should improve knowledge of mother, so the attitude toward toilet training implementation can to be better.
\end{abstract}

Keyword : Knowledge, attitude, Toilet Training, Toddler.

\section{PENDAHULUAN}

Istilah terrible twos sering digunakan untuk menjelaskan masa toddler, periode dari usia 12 sampai 36 bulan. Masa ini merupakan masa eksplorasi lingkungan yang intensif karena anak berusaha mencari tahu bagaimana semua terjadi dan bagaimana mengontrol orang lain melalui prilaku temper tantrum, negativisme, dan keras kepala. Meskipun bisa menjadi saat yang sangat menantang bagi orang tua dan anak karena masing-masing belajar untuk mengetahui satu sama lain dengan lebih baik, masa ini merupakan periode yang sangat penting untuk pencapaian perkembangan dan pertumbuhan intelektual ${ }^{1}$.

Dalam Undang-Undang Republik Indonesia nomor 32 tahun 2002 tentang perlindungan anak BAB III Hak dan kewajiban anak pasal 4 menjelaskan bahwa setiap anak berhak untuk dapat hidup, tumbuh, berkembang, dan berpartisipasi secara wajar sesuai dengan harkat dan martabat kemanusiaan, serta mendapat perlindungan dari kekerasan dan deskriminasi ${ }^{2}$. 
Salah satu dari aspek perkembangan anak yang dapat menghambat pertumbuhan anak salah satunya adalah pemenuhan kebutuhan toillet training.Toilet training adalah latihan berkemih dan defekasi dalam perkembangan anak usiatoddler pada tahapan usia 1 tahun sampai 3 tahun. Toilet training pada anak merupakan suatu usaha untuk melatih anak agar mampu mengontrol dalam melakukan buang air kecil dan buang air besar. Dan toilet training ini dapat berlangsung pada fase kehidupan anak yaitu umur 18 bulan sampai 24 bulan $^{3}$

Sejalan dengan anak mampu berjalan maka kemampuan sfingter uretra dan sfingter ani sudah mulai berkembang untuk mengontrol rasa ingin berkemih dan defekasi. Oleh karena itu orangtua harus diajarkan bagaimana cara melatih anak untuk mengontrol rasa ingin berkemih, diantaranya dengan menggunakan pot kecil yang bisa diduduk anak, atau langsung ke toilet pada jam tertentu secara regular untuk berkemih ${ }^{4}$.

Melalui toilet training anak akan belajar bagaimana mereka mengendalikan keinginan untuk buang air yang selanjutnya akan menjadikan mereka terbiasa untuk menggunakan toilet (mencerminkan keteraturan) secara mandiri. Kedekatan interaksi orang tua dengan anak dalam toilet training ini akan membuat anak merasa aman dan percaya diri. Hasil penelitian menunujukan bahwa ada hubungan signifikan antara peran orang tua dengan kebiasaan toilet training secara mandiri pada anak prasekolah ${ }^{5}$.

Anak-anak yang mulai belajar toilet training dalam usia dua tahun atau lebih besar akan terlambat untuk menguasai pengendalian kandung kemih. Akibatnya anak akan lebih sering mengompol di usia sekolah. Anak-anak yang terlalu lama dibiasakan menggunakan popok sekali pakai pada umumnya juga tidak bisa belajar mengosongkan kandung kemih mereka secara baik sehingga mereka lebih beresiko menderita nyeri saluran kemih karena kebiasaan menahan pipis.Menurut para peneliti dari Kanada yang meneliti beberapa riset yang sudah dipublikasikan menyimpulkan anak yang terlambat menguasai toilet training lebih beresiko menderita infeksi saluran kemih serta mengompol ${ }^{6}$.

Dampak toilet training yang paling umum dalam kegagalan toilet training antara lain adalah adanya perlakuan atau aturan yang ketat bagi orang tua kepada anaknya yang dapat mengganggu kepribadian anak atau cenderung bersifat ekfresif di mana cenderung bersikap keras kepala. Hal ini dapat dilakukan oleh orang tua apabila sering memarahi anak pada saat buang air besar atau buang air kecil, atau melarang anak saat berpergian. Bila orangtua santai dalam memberikan aturan dalam toilet training maka akan dapat mengalami kepribadian ekspresif dimana anak lebih tega, cenderung ceroboh, suka membuat masalah, emosionai dan sesuka hati dalam melakukan kegiatan sehari-hari ${ }^{3}$.

\section{TUJUAN PENELITIAN}

Diketahuinya hubungan pengetahuan dengan sikap ibu tentang pelaksanaan toilet training pada anak usia toddler di PAUD Tunas Ceria.

\section{METODE PENELITIAN}

Rancangan penelitian yang dilakukan adalah penelitian deskriptif korelasional denganmenggunakanpendekatan cross sectional. Populasi dalam penelitian ini adalah semua ibu yang mempunyai anak usia 1-3 tahun di PAUD Tunas Ceria yang sebanyak 44 orang. Metode yang digunakan dalam pengambilan sampel penelitian ini adalah dengan menggunakan metodetotal sampling 7 . Berdasarkan hasil penilaian skor jawaban yang diperoleh, pengetahuan dapat 
dikategorikan sebagai berikut ${ }^{8}$.

1. Baik dikategorikan $75-100 \%$ diberi kode 3

2. Cukup dikategorikan $65-75 \%$ diberi kode 2

3. Kurang baik dikategorikan $\leq 65 \%$ diberi kode 1

Penilaian sikap dapat dikategorikan sebagai berikut ${ }^{9}$ :

1. Baik, bila skor $\mathrm{T} \geq$ mean, diberi kode 2

2. Kurang baik, bila skor $\mathrm{T}<$ mean, diberi kode 1

Analisis data yang digunakan dalam penelitian adalah Pearson Chi Square.Uji Chi Square menggunakan bantuan komputerisasi SPSS versi 16.00 for windows yangdigunakan untuk menganalisis hubungan variabel kategori dengan kategori. Untuk mengetahui hubungan pengetahuan dan sikap ibu tentang pelaksanaan toilet training pada anak usia toddler digunakan taraf signifikan yaitu $\alpha(0,05)$ :

a. Apabila $\mathrm{p} \leq 0,05=$ Ho ditolak, berarti ada hubungan pengetahuan dan sikap ibu tentang pelaksanaan toilet training pada anak usia toddler. b. Apabila $\mathrm{p}>0,05=$ Ho diterima atau gagal menolak Ha, berarti tidak ada hubungan pengetahuan dan sikap ibu tentang pelaksanaan toilet training pada anak usia toddler.

\section{HASIL DAN PEMBAHASAN}

1. Karakteristik Subyek Penelitian

Adapun karakteristik subyek penelitian dijelskan dalam table 4.1 .

Berdasarkan tabel diatas menunjukan bahwa proporsi kelompok umur ibu paling banyak adalah berada pada umur ibu antara 26-30 tahun sebanyak 32 responden Pekerjaan terbanyak ibu adalah sebagai wiraswastasebanyak 18 responden $(40,1 \%)$ proporsi terbesar untuk pekerjaan responden Pendidikan ibu pada penelitian ini paling banyak Diploma/Sarjana dengan proporsi terbesar sebanyak 28 orang $(63,6 \%)$.

2. Pengetahuan Ibu tentang Toilet Training

Karaketristik responden berdasarkan kategori pengetahuan ibu tentang toilet training dapat dilihat dalam tabel 4.2.

Tabel 4.1 Distribusi frekuensi responden berdasarkan kelompok umur

\begin{tabular}{llcc}
\hline \multirow{2}{*}{ Variabel } & \multicolumn{2}{c}{ Responden } \\
\cline { 3 - 4 } & \multicolumn{2}{c}{$\mathbf{N}$} & \% \\
\hline Umur & 20-25 tahun & 5 & 11,4 \\
& $26-30$ tahun & 32 & 72,7 \\
Pekerjaan & $31-35$ tahun & 7 & 15,9 \\
& Ibu Rumah Tangga & 16 & 36,4 \\
& PNS & 10 & 22,7 \\
& Wiraswasta & 18 & 40,1 \\
& SMA/SMK & 16 & 36,4 \\
& Diploma/Sarjana & 28 & 63,6 \\
\hline
\end{tabular}

Tabel 4.2 Pengetahuan ibutentang toilet training

\begin{tabular}{llcc}
\hline & Variabel & Nesponden & \\
\cline { 3 - 3 } & & 25 & $\mathbf{\%}$ \\
\hline Pengetahuan ibu & Baik & 14 & 56,8 \\
& Cukup & 5 & 31,8 \\
& Kurang Baik & 44 & 11,4 \\
& Total & 100 \\
\hline
\end{tabular}


Tabel 4.3Karakteristik responden kategori berdasarkan sikap ibu tentang pelaksanaan toilet training

\begin{tabular}{llcc}
\hline \multirow{2}{*}{ Variabel } & \multicolumn{2}{c}{ Responden } \\
\cline { 3 - 4 } Sikap ibu & Kurang baik & N & \% \\
& Baik & 19 & 43,2 \\
& Total & 25 & 56,8 \\
& & 44 & 100 \\
\hline
\end{tabular}

Tabel 4.4 Tabulasi Pengetahuan dengan Sikap Ibu Tentang Toilet Training

\begin{tabular}{lccccccc}
\hline \multirow{3}{*}{ Pengetahuan Ibu } & \multicolumn{5}{c}{ Sikap Ibu } & \multirow{2}{*}{$\mathbf{X}^{2}$} & \multirow{2}{*}{$\boldsymbol{p}$} \\
\cline { 2 - 5 } & \multicolumn{2}{c}{ Kurang Baik } & \multicolumn{2}{c}{ Baik } & & \\
\cline { 2 - 6 } & $\mathbf{N}$ & $\mathbf{\%}$ & $\mathbf{N}$ & $\mathbf{\%}$ & & \\
Kurang Baik & 1 & $20 \%$ & 4 & $80 \%$ & & \\
Cukup & 10 & $71,4 \%$ & 4 & $28,6 \%$ & 6,922 & $p: 0,031$ \\
Baik & 8 & $32 \%$ & 17 & $68 \%$ & & \\
\hline
\end{tabular}

Berdasarkan tabel diatas diketahui bahwa pengetahuan ibu tentang toilet training paling banyak adalah tingkat pengetahuan baik sebanyak 25 responden ( 56,8\%) dari 44 responden, tingkat pengetahuan cukup sebanyak 14 responden $(31,8 \%)$ dan tingkat pengetahuan kurang baik sebanyak 5 responden $(11,4 \%)$.

\section{Sikap Ibu tentang Pelaksanaan Toilet Training}

Karaketristik responden berdasarkan kategori sikap ibu tentang pelaksanaan toilet training dapat dilihat dalam tabel 4.3

Berdasarkan tabel diatas diketahui bahwa sikap ibu tentang pelaksanaan toilet training paling banyak adalah mempunyai sikap baik sebanya 25 responden $(56,8 \%)$ dari 44 responden, dan yang mempunyai sikap kurang baik sebanyak 19 responden $(43,2 \%)$.

4. Hubungan pengetahuan dengan sikap ibu tentang toilet training di PAUD Tunas Ceria.

Penelitian ini untuk mengetahui hubungan pengetahuan dengan sikap ibu tentang pelaksanaan toilet trainingdi PAUD Tunas Ceria. Untuk mengetahui hal itu selanjutnya data penelitian dianalisis dengan uji Chi Square, berdasarkan data pengetahuan dengan sikap ibu tentang pelaksanaan toilet training di PAUD Tunas Ceria disajikan pada tabel 4.4.

Dari hasil tabel 4.4 di atas diketahui bahwa responden dengan pengetahuan yang baik memiliki sikap yang baik sejumlah 17 (68\%) responden, pengetahuan yang kurang baik memiliki sikap yang baik sejumlah $4(80 \%)$ responden, dan pengetahuan yang baik mempunyai sikap yang kurang baik sejumlah 8 (32\%) responden.

Sedangkanhasil uji Chi Square dengan tingkat kepercayaan95\% atau $p: 0,05$ dengan Asymp. sig. (2-sided) yaitu 0,031. Hal ini menunjukkan bahwa nilai $p<0,05$, menunjukkan bahwa terdapat hubungan signifikan antara pengetahuan dengan sikap ibu tentang pelaksanaan toilet training pada anak usia toddler di PAUD Tunas Ceria Yogyakarta.

Dari hasil penelitian tersebut didapatkan total tingkat pengetahuan ibu anak usia toddler di PAUD Tunas Ceria dapat dikatakan berada pada tingkat pengetahuan baik, total jumlah dari 44 responden $25(56,8 \%)$ responden berpengetahuan baik, 14 (31\%) responden berpengetahuan cukup 
dan hanya 5 (11,5\%) yang berpengetahuan kurang. didapatkan umur terbanyak responden berada pada kisaran umur 26-30 (72,7\%), pendidikan terbanyak adalah SMA 40 (90,9\%), dan pekerjan paling banyak adalah Ibu Rumah Tangga $32(72,7 \%)^{12}$. Faktor-faktor yang mempengaruhi sikap yaitu : pengalaman, kultur (budaya, agama), pendidikan, sosial ekonomi. Dari data tersebut mulai dari umur yang tergolong masih muda, pendidikan mayoritas SMA dan pekerjaanpun terbanyak adalah Ibu Rumah Tangga sehingga akan berpengaruh pada pengalam, pendidikan dan berdampak pada tingkat pengetahuan.

Sebuah penelitian menyatakan bahwa ada korelasi terbalik yang kuat antara tingkat pendidikan ayah dengan penerapkan hukuman untuk pelatihan dan korelasi langsung antara penolakan toilet dan usia lanjut menyelesaikan pelatihan toilet ( $\mathrm{LR}: 6,3, \mathrm{P}<0,05$ ). Usia rata-rata menyelesaikan pelatihan toilet adalah sekitar 23 bulan $^{10}$.

Data sikap didapatkan sikap baik 4 (80\%) responden dan sikap kurang baik $1(20 \%)$ responden dengan pengetahuan kurang, sikap baik $4(28,6 \%)$ responden dan sikap kurang baik 10 (71,4\%) responden dengan pengetahuan cukup, sikap baik 17 (68\%) responden dan sikap kurang baik 8 (32\%) responden dengan pengetahuan baik.

Faktor-faktor yang dapat mempengaruhi sikap adalah pengalaman pribadi, kebudayaan, orang lain yang dianggap penting, media massa, institusi/ lembaga pendidikan dan lembaga agama, faktor emosi dalam diri individu dan pengetahuan. Faktor tersebutlah yang dianggap kenapa ibu dengan pengetahuan kurang baik dapat mempunyai sikap yang baik ${ }^{9}$.

Dari hasil tersebut, sama dengan hasil pe nelitian ${ }^{11}$ Hukmawati, (2013) yaitu ada hubungan tingkat pengetahuan dengan sikap ibu tentang toilet training di Desa Lambang Kuning Kecamatan Lumbang Kabupaten Probolinggo mendapatkan hasil dari total 63 responden dengan hasil pengetahuan paling banyak $24(38,1 \%)$ adalah kategori pengetahuan yang kurang baik sehingga akan mempengaruhi sikap responden yaitu $38(60,3 \%)$ responden mempunyai sikap kurang baik dengan karakteristik responden usia ibu terbanyak pada usia 20-30 tahun yaitu 41 $(65,1 \%)$ responden, pendidikan terbanyak yaitu SD $51(80,9 \%)$ responden, dan pekerjaan ibu adalah IRT sejumlah $54(85,7 \%)$ responden.

Dari hasil tersebut, sesuai dengan teori yang ada bahwa pengetahuan dan sikap mempunyai keterkaitan hubungan terutama dalam komponen kognitif pada sikap.Selain itu pengetahuan merupakan dominan yang penting untuk terbentuknya tindakan seseorang (over behavior). Pengetahuan seseorang terhadap suatu objek akan menimbulkan respon batin dalam bentuk sikap terhadap objek yang diketahui sehingga menimbulkan respon yang lebih jauh lagi yaitu berupa tindakan (action) atau prilaku. Prilaku yang didasari oleh pengetahuan akan lebih langgeng (long lasting) daripada prilaku yang tidak didasari oleh pengetahuan ${ }^{11,12}$.

\section{SIMPULAN DAN SARAN}

\section{A. Simpulan}

Berdasarkan tujuan penelitian dapat diambil simpulan sebagai berikut :

1. Pengetahuan ibu tentang toilet training di dapatkan data jumlah dengan kategori baik serjumlah $25(56,8 \%)$ responden, kategori cukup serjumlah $14(31,8 \%)$ responden, dan kategori kurang baik serjumlah 5 (11,4\%) responden.

2. Sikap Ibu tentang pelaksanaan toilet training didapatkan data jumlah dengan kategori baik sejumlah $25(56,8 \%)$ responden, dan dengan kategori kurang baik sejumlah 19 (4,2\%) responden 
3. Ada hubungan antara pengetahuan dengan sikap ibu tentang pelaksanaan toilet training pada anak usia toddler di Tunas Ceria.

\section{B. Saran}

1. Bagi Ibu Anak Usia Toddler di PAUD Tunas

Ceria

Diharapkan Ibu mengupayakan peningkatan pengetahuan tentang toilet training pada anak usiatoddler dengan mencari informasi yang baik dan akurat sehingga pengetahuan dan sikap yang masih kurang baik dapat dirubah menjadi baik sehingga pertumbuhan dan perkembangan anak akan berjalan maksimal.

2. Bagi Institusi PAUD Tunas Ceria

Sebagai bahan pertimbangan dalam pengupayaan pengoptimalan tumbuh kembang anak dengan menyebarluaskan informasi tentang pengetahuan dan sikap ibu tentang pelaksanaan toilet training.

3. Penelitian Selanjutnya

Penulis berharap pada penelitian-penelitian selanjutnya untuk meneliti faktor yang lebih kompleks pengaruhnya terhadap sikap, selain faktor pengetahuan.

\section{DAFTAR PUSTAKA}

1. Wong, D. L. (2009). Buku Ajar Keperawatan Pediatrik, Edisi 6, Volume 1. Jakarta: EGC.

2. Undang-Undang Republik Indonesia nomor 32 tahun 2002 tentang Perlindungan Anak

3. Hidayat, A. A. (2005). Pengantar Ilmu Keperawatan Anak. Jakarta: Salemba Medika

4. Wong, D. L. (2008). Buku Ajar Keperawatan Pediatrik, Edisi 6, Volume 1 . Jakarta: EGC. 
Hubungan Pengetahuan dengan Sikap Orang Tua Tentang Toilet Training pada Anak Toddler di Paud Tunas Ceria

5. Trisnawati. (2013). Hubungan Peran OrangTua Dengan Kebiasaan Toilet Training Secara Mandiri Pada Anak Prasekolah Di TK 'Aisyiyah Bustanul Athfal Palur 02

Kabupaten Sukoharjo. http://digilib.stikes-

aisyiyah.ac.id/gdl.php?mod=browse\&op=read

\&id=stkaisyiyahska--ekaratnatr-37 diperoleh

24 Desember 2013.

6. Anna, L. (2011). Segera Ajarkan Balita Toilet Training. http://health.kompas.com/ read/2011/08/10/08042557/Segera.Ajarkan. Balita.Toilet.Training. diperoleh 19 Agustus 2013diperoleh 14 Desember 2013.

7. Sugiyono. (2011). Metode PenelitianKombinasi (Mixed Methods). Bandung: Alfabeta.

8. Arikunto, S. (2010). Prosedur Penelitian Suatu

Pendekatan Praktik. Jakarta: Rineka Cipta

9. Azwar. (2013). Sikap manusia : Teori dan Pengukurannya. Yogyakarta; Pustaka Pelajar Offset

10. Hooman, N (2013), Pelatihan Toilet Pada Anak Irian. http://www.ncbi.nlm.nih.gov/pmc/ articles/PMC3663305/ didapat 18 Februari 2014.

11. Hukmawati, N (2013) Hubungan Tingkat Pengetahuan Dengan Sikap Ibu Tentang Toilet Training Di Desa Lambang Kuning Kecamatan Lumbang Kabupaten Probolinggo. http://www.stikeshafshawaty.com/index.php/ jurnal-div-bidan-pendidik/80-attitude-toilet- training

12. Notoatmojo, S (2007). Promosi Kesehatan dan

Ilmu Prilaku. Jakarta; Rineka Cipta 